\title{
Didemoversity: The Core of Democracy at the Heart of the Modern University
}

\author{
Julia M. Puaschunder ${ }^{1,2}$ \\ ${ }^{1}$ The New School, Parsons School of Design, Department of Economics, 6 East $16^{\text {th }}$ Street, $9^{\text {rd }}$ floor 89, New \\ York, NY 10003, USA, Julia.Puaschunder@newschool.edu, T 001212229 5700, F 0012122295724, \\ www.juliampuaschunder.com \\ ${ }^{2}$ Columbia University, Graduate School of Arts and Sciences, Julia.Puaschunder@columbia.edu, \\ http://blogs.cuit.columbia.edu/jmp2265
}

\begin{abstract}
The currently skyrocketing digitalization disruption in the wake of COVID-19 holds the potential to revolutionize higher education. Digitalized education and conglomerates in the educational sector may lead to universities becoming truly global temples of information exchange. The lockdowns have also steered a wave of emotional outcry for social justice and participatory decision making. Future universities may thus also focus on embracing collective decision making and participatory leadership through the students. The future Didemoversity will thus likely feature elements of digitalization globalization and hallmarks of democracy such as participation in flat hierarchies to pursue a higher goal of universities to become social transformers and great equalizers.
\end{abstract}

KEYWORDS: Conglomerates, Collective decision making, COVID-19, Democracy, Didemoverity, Education, Equality, Inequality, Lottery, Participatory decision making, Social justice, Social transformation

\section{International conglomerates in virtual spaces}

The new Coronavirus (COVID-19) pandemic is an external shock that accelerates an already ongoing digitalization disruption but also steered an outcry for social justice and participatory change. Despite the enormous economic growth decline already obvious and prospected in the years to come, the digitalization disruption will impact education bestowing it a truly international outlook. One of the most powerful ways to enjoy luxury in the digital age is online education, which now has leveraged into a truly international experience.

COVID-19 unleashed the online technology world. Physically distanced, we became digitally closer than ever. On a flat globe, data traffic exploded. A multi-tasking online workforce gained global outreach and flexibility in digitalization cutting red tape (Puaschunder 2020c). The digitalization trend has become prevalent in education. Since the outbreak of the 2019 novel Coronavirus crisis, COVID-19 entailed massive changes in the education sector (Corlatean 2020). Teachers, pupils and students, parents, schools and local communities and, last but not least, the state were suddenly put in a position to change their rules of operation, teaching techniques or examination methods (Corlatean 2020).

With most university campuses around the world currently performing a speedy transition to online teaching and remote learning, it is certain that hybrid learning and online classwork will be perks that last forever, even after COVID-19 will have its influence on our behavior. Disruptive technology use will enable universities to cater education to the whole world at low cost and offered flexibly to students without any consideration of their location. The actual on site work are likely to be focused on research, while learning will be more likely to happen online in the virtual space. Large networks that allow swapping and sharing courses within a larger and global online consortia of universities around the world and the industry or governments will take over. 
Disruptive technologies will be effective at helping students around the globe and open doors for studying "abroad" to everyone. Taking classes remotely lower costs for universities and students alike. Market segmentations will take place for high-end physical learning experiences versus low-cost online experiences. The division in these categories will likely depend on the field of study. But also hybrid short-term physical experiences coupled with online teaching are creative market options. The hybrid could be between subjects but also within a class it would be possible that students are choosing to be physically present for a premium price and the cheaper option online is sold at the same time offering virtual attendance and even cheaper solutions over time in terms of selling recordings of the same class to be watched lateron.

Classes will also open up free from visa and administrative hurdles. So the digitalization disruption may become a social upward mobility vehicle that opens access to elite education to previously politically unfavorable visa applying nationals. Education therein has the potential to be the great equalizer international development has wished for ever since. Future partnerships of the technology and universities governed by international institutions will offer a broad range of hybrid online-offline teaching solutions in ample virtual spaces that serve as truly international educational hubs.

Access to virtual consortia will also offer opportunities to cherry-pick an individualized education based on interests and afar from physically reachable learning repertoires. Past mass teaching with a cohort of similarly educated will pass for a new cadre of individualized and highly specialized graduates that could select very individualized study schedules based on their specific needs and wants at a certain point in their careers. For this, the institutional support and openness to accept courses within the conglomerate consortium has to be emphasized. With the currently ongoing digitalization disruption requiring more and more refined skills in a world where the gap between skilled and unskilled labor has become the widest, the time for refined and individualized education appears to have come.

\section{Life-long education}

Universities with students that do not have to attend campus classes not only can offer flexible education with broad international outreach. Not having to be on one particular campus offers two flexibilities: international but also over time. Online classes can be attended by people from around the world. But also with no relocation costs and visa requirements having to be met, individuals are able to remain in education longer and more flexibly. Online degrees that can be acquired over long time become reasonable if people only have to attend a week a year, during which they may choose to get educated on a specific subject they need right at the moment in time in their career. Imagine signing up for a 10 year MBA program that is completed with one course per year over a decade. The advantage would be a long-term bond with education institutions and temporally flexible education - picking educational contents at the right moment in time in one's career. Interests change, so do career-specific needs, not to mention the overall economy and societal trends. Virtual students of the future could sign up for a life-long career enhancement package. Students would not have to live off old degrees that have buckled them up for a specific field that was picked in their youth and that was studied in the past. Anachronic education and locked-in professional fields could shift to timely classes that are diverse over time. Especially in highly flexible fields, such as IT, medicine or law, in which constant education is mandatory and/or necessary, an as such long-term online degree would be beneficial to go with the time and bring back continuous legal or medical education requirements back on campus. In addition, the signing up for such a long term degree accomplishment process may be easier as it stretches out reduced online costs over time. Further, the emotional bond to institutions may grow over the long term, and educational and reputational capital can be maximized to be harvested for a long 
time by the students. For the universities that are highly dependent on alumni donations this model of a life-long university relation with a career-professional would secure the continuous financialization stream and help continue the dialogue with students long-term.

A market polarization is expected, in which the big conglomerates may swallow smaller and financially weaker colleges. The universities that will likely offer these kind of programs are the large Ivy Leagues, who can wait out the pandemic given large endowments, constant stream of funding from alumni and students drawn from waitlists while the pandemic and visa requirements are drying continuous enrollment flows. These are the ones that will outwait the smaller and lower tier colleges that are dependent on tuition. Being flexible to adapt and partner with technology providers but also being in a favorable location will likely be beneficial features of the universities of tomorrow. These universities surviving the COVID19 crisis will be able to expand their enrollment dramatically, once they transitioned effectively into remote online teaching and the market has accepted this new normal. Universities that are not able to adapt to online teaching or are not even close to a consortium solution are expected to be in financial constraints. Already in 2020, North American universities are reporting revenue losses in the hundreds of thousands stemming from missing international applicants and dormitory and canteen revenue losses.

\section{Social justice transformation}

Democracy enables individual and political freedom, political equality and participation of all citizens. In its foundation, democracy set out to enable to structure the rule of law and the citizens in relation to the political and state power. Democracy was meant to establish the necessary means of groups to be ruled by the majority. Rule of the citizens as demos (the people) was represented in all spheres of life, ranging from trade to production and knowledge generation to conservation as well as public discourse to law and order. The concerted action of citizens was means to become politics for all. Collective decision over common goods was chosen to breeding social harmony during an ancient time with diverse populations.

Democracy started in the $5^{\text {th }}$ century before Christ in the political realm of states of Attica, today's Athens in Greece. The ancient Athenian city state transformed from a monarchy (rule of one), to an oligarchy (rule of some) to a democracy (rule by the people for the people with the people) as Aristotle and other philosophers and statesmen praised civic participation and direct engagement (Stüwe \& Weber 2004). Democracies were sought to preserve freedom for the people under the laws they have established concertedly. In a democracy, it commonly-agreed upon laws are guarding the people and the constitution of the state. Rule of law preserves freedom of citizens (Eder 1995; Osterwald 2011).

In order to avert a social crisis and poverty, a large-scale debt reduction plan of the Senate of 400 worked on describing the general population, categorizing all citizens into 4 classes based on wealth. Under the reign of Archontat a Senate of nobilitas was created. Farmers and poor were freed and their debts were cancelled to overcome socio-economic misery.

Around 624 before Christ, Drakon established a powerful rule of law and wrote down the civil code. During this time, rules were changed that not family heritage but income would determine power. Around 594 before Christ, Solon then parted the citizens into 4 classes for determining diversified democratic participation and voting rights. The Senate of the 400 was drawn from all four Athenian citizens groups. A general assembly that participated in all legal action and rule of law was established. Highest citizens would become highest ranked officials, such as treasurers. Everyone could apply for public offices, such as judges and civil servants. Those parts of the population without fortune had the active voting right, but no passive to being voted into office. A census was established. In its beginnings, democracy was meant to bridge the gap in the divide of the population in the rule of nobilis 
versus tyrannis splitting of the leadership, reigning and opposition of civilian society (Stüwe $\&$ Weber, 2004). Democracy was chosen to enact Isonomy (equal rights in front of the law to all), Isegory (equal rights of speech) and Isocracy (equal rights to rule).

Around 509 before Christ, Cleisthenes established democracy and changed power of tyrannis and established a political will of the citizens (Frevel, 2006). Historically, Cleisthenes reformed the political power of the free, making them independent from the nobilitas as they gained vote on their own political representatives into the Senate. In the beginnings of democracy, education was to control rule of law and cultivate a high civil culture (Sintomer, 2016). Cleisthenes' reform gave more power to demos and general assembly by forming a Senate of the 500 for daily administrations and decision making for the people. Cleisthenes established democratic tribunals (Heliaia) and democratic Senates (Boule) as a counterpart to the aristocratic Senate (Areopag). 483 before Christ Themistocles opened democracy for citizenry groups. Pericles followed this trend by giving more rights to foreigners with parents that were not from Athens. Peisistratus lowered the power of land possessing nobilitas to then give more rights to farmers, which led to the economic and cultural uprise of Athens and a general mobilization of citizens' forces.

Around 462-458 before Christ, Epilates and Pericles reformed how political decision are made by the Senate, courts and Assembly. Every citizen was meant to gain an understanding of democracy. Athenian democratic politics under Pericles were founded on a constitution that was called a democracy granting power in the hands not of a minority but of the whole people (Eder 1995). Freedom and equality of those who reign and those who are reigned were established through participation and self-determined crafting of laws that were voted on by rotating members of the community (Eder 1995). Private disputes were settled with everyone being equal before the law. Lottery was to evade bribery and clique (Eder 1995).

Pericles also introduced payment for jury service as the first of the state's civilian stipends, to make service attractive to the poorer citizens and enable a democratic institution to work in a democratic way. The third wealth class was enabled to join the citizenry and diets. Diets were daily allowances so that those serving the state following a lottery draw could be absent from their work and lottery of the citizen Tribuneral. The daily funds given to the citizens enabled the economic possibility to join the Senate and participate in juries without their families incurring financial or economic drawbacks of missing heads of families, who served in the state, for instance in the general assembly the ecclesia.

Democracy changed the social class system by giving power to local communities with self-ruling administration. All citizens were enabled to participate in the general assemblies to vote for laws and the judge in trials. Politics of democracy enabled citizens to rule the state. Via the lottery system, equality of all existed in elections of magistrate via lottery and responsibility of magistrates. Rule of the people was ensured by the participation in all public offices, like the Senate and the General Assembly. A lottery system opened representatives of the districts that helped in the organization of the city. Every citizen could be part of the Assembly as the lottery system enabled that intensified political participation of all in-power with no singular leadership. Overall, almost 6,000-8,000 citizens took part in the general Assembly per year over 40 days a year (Sintomer 2016). Democracy of politics of civil action were driven by the self-determination and the active participation of its people, who as civilians felt that they could shape the nature, state and form of their government.

Senate of the 500 Boule featured up to 1,200 citizens over its existence, or around 5\% of the population. The Senate of the 500 gave every citizen the right to participate in democracy. The 600-700 Boule members were drawn by lottery, who helped the national Assembly in drafting laws, appointing judges and making military decisions and foreign policy as well as controlling the administration and state finance (Sintomer 2016). About $70 \%$ of the citizens above 30 were once in their lives part of the Boule serving in the judiciary branch. 
The Senate proposed common decisions, which are approved in the ecclesia. All judges are drawn by lottery and every year about 6000 citizens were drawn as jury judges. Citizens are thereby directly related to law, general assembly decisions making and serving as advisors to the community (Sintomer 2016).

Public positions were drawn by lottery and every citizen could sue and be held accountable (Philipp 2000). Public officials had to justify their spending at the end of their terms. If leaving a farm to hold a public office, diets were paid. Lottery was meant to bring equality to life and to avoid pre-negotiations and nepotism as well as corruption in city and state placements. Participatory decision making was meant to enact common solution finding, acceptance of choices and breed social harmony in a highly diverse society.

The ecclesia was at the heart of democracy to meet in frequent intervals and discuss a broad range of issues among the people. Every citizen was enabled to file for legislation changes and could thereby impose democratic will without any repression or economic drawbacks. During the Pericles reign, thereby out of the 3-50,000 citizens about $1 / 4$ of the over 30 years old could hold a public office. Of the 10,000 male citizens, around 6-8000 thereby became a vital part of the active democracy. Polis was organized such that free and equal could rule over free and equal (Eder 1995).

Freedom of speech became a means to protest against the nobilitas and concerted decision making in the Assembly (Frevel 2006). Democracy in its core founded the ideals of a democratic state being ruled by equal rights, freedom of speech, common assembly and written down laws that are right, just and fair for every citizen (Frevel 2006).

The lottery system became to starkest form of organized radical democracy and had its heights during the golden ages of the Athenian democracy from the $5^{\text {th }}$ to the $4^{\text {th }}$ century (Sintomer 2016). Lottery could draw from people with but also without their knowledge. In lottery and a rotation of positions about $1 / 4^{\text {th }}$ to $1 / 3^{\text {rd }}$ of the male citizens above 30 years became part of the government in the ancient Athenian city state. Citizen thereby truly acted as a part of the community, being in a roaster for aiding in the state. Civilians were put into power for a part of the year for the Senate and for a month to become members of the executive branch (Sintomer 2016). Every citizen could be part of the lottery, which also attributed the responsibilities within the Senate that was composed by representatives of the population. The Senate was voted by lottery - its representatives were only allowed to be active once for a months and the head was only active for a day (Sintomer 2016). The Senate then was the institution within the Athenian democracy that divided legislative, executive and judicial powers. Rotation of positions ensured that individuals were not repeated and that everyone had an equal chance in terms of political participation. In all these features, the lottery system grants hope of all citizens in true participation. Problems are the full inclusion in ancient lottery forms - for instance, in the antique Athenian city state, non-citizens, children, women and slaves were excluded to be drafted - and risks of not being qualified or responsible citizens did, however, occur (Philipp 2000).

Lottery and direct democracy through a general Assembly and people jury as well as diverted political, judiciary and military rotation of power helped also other powerful ancient and modern democracies to breed social harmony and civic participation in a collective decision making. Athens, Rome, Venice, Florence, Spain and even China at some point had lottery systems during the height of ancient Republics. In the Roman Empire and Florence under the Medici during the $13^{\text {th }}$ and $14^{\text {th }}$ centuries but also in early Spain, lottery systems were chosen to evade disputes and breed social cohesion. Florence enacted a highly sophisticated draft to influential public offices based on the credibility, tax contribution and abstinence of crime.

Switzerland had lottery drafts until the 1800s. James Harrington in the British colony of America argued for direct democracy and lottery draft during the $18^{\text {th }}$ century. During the European monarchs, the so-called Fürstenspiegel was meant as a civic checks-and-balances 
of the leadership of the reigning class as a precursor of democracy. Great Britain had a stratified random selection to public offices (Philipp, 2000). William Penn argued for direct democracy in the Constitution for New Jersey and Thomas Paine for the appointments in the US Congress. Massachusetts, New York, Connecticut and New Hampshire had some kind of lottery draft between 1736 and 1758, New Jersey and Maryland between independence and 1800 (Philipp 2000). The values conveyed in the idea of direct democracy, including participation and rule by all inspired revolutions, such as the ones of France and America (Tocqueville, 1835). To this day, democracy is a hallmark of modern society. The rule of the people was brought to life in Abraham Lincoln's advocacy of enacting a government of the people, by the people and for the people. Political economy of race has been inspired by the ideas of equality. The representative draft serves as a micro-cosmos of society (Philipp 2000). In 1968, the US Congress passed a law for draft for juries based on a fair cross section of the community. Juries were presented for bills to better regulate as fair, neutral and without party affiliation or personal interests. As guardians of public justice, jury drafts to this day enable political novices in common law countries to judge as an enactment of participatory democracy and egalitarian society (Philipp 2000). To this day, lottery jury systems are praised as self-regulating democratic act and serve as a foundation of common law and democratic participation (Tocqueville 1835). Petition drives and Volksbegehren are until now common in Europe and the USA, in which citizens can point attention of the legislation to issues of concern or legal reform.

\section{Democracy and education}

Soaring income inequalities and a declining American middle class coupled with visa restrictions for international students, the North American higher education system has become under distress since the turn of the millennium (Benjamin \& Ferguson 2020). A stratified market with only a handful of private universities or a few refined fields offering a clear prospect of a return on investment, demands for building internationally competitive programs with ample endowments, governmental, industry and alumni funding streams (Benjamin \& Ferguson 2020). Many colleges addressing financial constraints even before COVID-19, increasingly embraced to include out-of-state students who pay full cost. They sought to attract students from abroad, including many from China (Benjamin \& Ferguson 2020). With suffering from revenue losses in the wake of COVID-19, many of the non-first-tier institutions are currently heading towards major financial constraints that demand for a rethinking of the financialization strategy of higher education (Benjamin \& Ferguson, 2020; Corey 2020; Finkelstein, Conley \& Schuster 2016).

The current Coronavirus crisis pushing digitalization and social justice reform via participatory action, now has set the stage for a Didemoversity trend. Di-demo-versity thereby integrates the current digitalization, core values of democracy coupled with the main functions of a university. Digitalization will focus on international virtual consortia to create online virtual spaces to learn and thrive. Democratic participation will bond students to their learning realities. Universities should continue their mission to educate and foster research but should also play a vital role in becoming social transformers for the enactment of social justice.

The Didemoversity could go back to values of Pericles that the members of the community have to make decisions by themselves and find out what is right, just and fair rather than just take the law or market mechanisms to order their behavior. With the world 'university' stemming from the ancient Latin word for 'whole,' the Didemoversity should pay tribute to draw from all its members' human capital to carve out the overall strategy of the university (Corey, May 7, 2020).

The Didemoversity will take up core democratic visions such as the lottery, rotation and participation in politics and administration, justification of spending and general assembly. 
Ideals of democracy or all citizens to be equal with the same freedoms will be addressed in flat online virtual worlds that will foster shared ideas and exchange of information more boundlessly. Power will be bestowed to the students, who come together in virtual worlds to discuss ideas and share their opinions to form strategies how to change the world.

In the Didemoversity model, students should gain an understanding of political action and democracy naturally by enabling a democratic university and classroom experience. The current drive towards an online gateway to the university will create a flatter space to approach different hierarchies. On a flat globe, students will be encouraged to actively take a stance on university agendas. Participatory decision making in studies and university management will engage and motivate students, who meet in online virtual spaces. Students will become a vital part of an informed administration that reflects the heart and souls of the student body, rather than being a detached administrative representation of individuals who have no personal skin in the game or are not formally educated and qualified. In a rotation of functions, students should be enabled to participate in the decision making of the university that surrounds them.

As for the blatant social justice demands of our times, a democratisation of the educational curriculum should aid future leaders to understand the political agenda of their times and directly enact social justice strategies. Universities of tomorrow could thereby become the ultimate hubs of citizenship education. Democracy at university could serve as an ultimate peace strategy that is practices by the students as a way to harness their citizenship rights in regards to social justice. The Didemoversity should open a forum to discuss the public agenda and judge on the future endeavours of the institution. Participation and deliberation will create a sense of belonging, even when switching online.

Higher education as a principal avenue for the transmission of human capital and learning to new generations. Makes Didemoversities essential in today's digital world in which college graduates will need critical thinking skills to survive. Colleges and universities are also central to serious efforts to rectify inequalities of income and wealth (Benjamin \& Ferguson 2020). The crisis can be interpreted as system change accelerator that hold advantages to shift to online teaching and international outreach. Both students and faculty should be represented on the boards of all institutions to reduce wishful thinking by administrators about the real conditions of campus life (Benjamin \& Ferguson, 2020).

Today's racial disparity and socio-economic crisis stemming from systemic racism also demands for a debt reduction in higher education to release underprivileged groups from debt burdens hindering their full potential. The life-long financialization of past endeavours in debt repayment mentally locks underprivileged groups to be vital parts of the economy, to grow into entrepreneurs or future visionaries.

The Didemoversity could become a playground of deliberative democracy in the notion of John Rawls and Jürgen Habermas. Didemoversities could serve as most vibrant laboratories of ideas in a contestable democracy (Loewenstein 1957). Petition drives and Bürgerbegehren could carve out the structure and goals of the Didemoversity. Direct participation and a deliberative survey in the hope of participatory action enacted by the lottery among all university students would empower a truly global student body. Academics could learn during their studies how to renew dreams of equality and establish socially just democracies. In a self-regulatory radical democracy, natural behavioral laws of what is right, just and fair would be established by the students, for the students and with the students. Deliberation would also mobilize the knowledge of the institution in public gremia and participatory action. The Didemoversity thereby tabs into an already ongoing trend of permanent faculty passing positions to adjuncts or student teaching fellows and assistants from $85 \%$ in 1970 to less than $25 \%$ today (Benjamin \& Ferguson 2020). 


\section{Discussion}

In the future, it remains on tech-entrepreneurs and social justice transforming institutions and activists, breaking the most innovative waves to implement the Didemoversity in the Digital Age whilst upholding highest ethical standards (Puaschunder 2017c). To boldly envision, design and craft the virtual luxury platforms of tomorrow connecting us for collective information exchange fueled by emotional participation in common learning platforms. But the beauty of enjoying lavish network effects and delving into world-wide collective emotional feasts also bears a responsibility to worship our common virtual luxury temples together wisely, conscientiously and sustainably (Puaschunder 2019, 2020a, b).

The new approaches to teaching and learning also imply novel inequalities in regards to private learning spaces and access to information dependent on the level of digitalization and internet connectivity. With access to healthcare and education in virtual luxury boutiques we need to rethink democratization of internet access and online availability. Public and private sector forces on the local, national, international and global levels should bundle and cross-pollinate to find create ways in embracing the masses equally with connectivity. Ethical cliffs of online access and technology affinity determining access to health, education and emotional well-being should be outlined in order to avert societal downfalls.

While the affordability of entering these virtual spaces will serve as a great equalizer offering access to affordable education around the globe, there may be the risk of an inflation of many degrees offered to students without any space constraints and a discreditation of already existing degrees lurking. Additional problems arise from missing real in-person learning and on-campus networking opportunities. Children staying with their parents to take classes may grow up less attentive to be around people their age, and there may be the risk of social isolation, heightened levels of depression and a generation of socially awkward geeks without empathy coming up in contrast to students that have had the real world learning experience in classrooms. However, if we can lower the cost of education for the upcoming generation, the educational debt burden may be lifted that was recently referred to by the New York Federal Reserve as to be putting generation internship into a prison of debt from which they cannot escape even after graduation. Virtual learning experiences may also shun students from all social-psychological burdens and peer-pressure downfalls of on-campus education if we manage to create virtual spaces upholding a healthy climate of online exchange grounded in mutual respect, ennobling culture of ethics and embracing diversity in elevating levels of inclusiveness. Overall, Didemoversities offer hope to imbue the dignity and nobility that core democratic values into our universities and digitalization can become the means to convey this spirit on a global scale.

\section{References}

Benjamin, Roger \& Thomas Ferguson. 2020. Are American colleges and universities the next COVID casualties? New York, NY: Institute for New Economic Thinking (INET), October 31, 2020.

Corey, Robin. 2020. "The pandemic is the time to resurrect the public university." The New Yorker, May 7, 2020.

Corlatean, Titus. 2020. "Risks, discrimination and opportunities for education during the times of COVID-19 pandemic." Proceedings of the $17^{\text {th }}$ International RAIS Conference on Social Sciences and Humanities, pp 37-46, on June 1-2, 2020.

Eder, W. 1995. Die athenische Demokratie im 4. Jahrhundert v. Chr.: Vollendung oder Verfall einer Verfassungsreform? Stuttgart: Franz Steiner.

Finkelstein, Martin, Valerie Conley \& Jack H. Schuster. 2016. The faculty factor: American academy in a turbulent era. Baltimore, MD: Johns Hopkins University Press.

Frevel, B. 2006. Demokratie: Entwicklung, Gestaltung, Problematisierung: Elemente der Politik. Wiesbaden: Verlag für Sozialwissenschaften. 
Loewenstein, K. 1957. Political power and the governmental process. Chicago: The University of Chicago Press.

Osterwalder, F. 2011. Demokratie, Erziehung und Schule. Bern: UTB.

Philipp, M. 2000. Demokratie und Legitimation: Verfahrens- und Entscheidungsprozesse in Staat, Gesellschaft und Wirtschaft demokratischer Gemeinwesen: Interdisziplinäres Seminar der Universität Augsburg an der Universität Osijek. Aachen: Shaker.

Puaschunder, Julia Margarete. 2017c. "Nudgitize me! A behavioral finance approach to minimize losses and maximize profits from heuristics and biases." International Journal of Management Excellence, 10(2), 1241-1256.

Puaschunder, Julia Margarete. 2019. "Artificial Intelligence market disruption." Proceedings of the $17^{\text {th }}$ International RAIS Conference on Social Sciences and Humanities organized by Research Association for Interdisciplinary Studies at Johns Hopkins University, Montgomery County Campus, Rockville, MD, United States, June 10-11, pp. 1-8.

Puaschunder, Julia Margarete. 2020a. Data fiduciary in order to alleviate principal-agent problems in the artificial big data age. 46th Eastern Economic Association Conference, Boston Sheraton, Boston, Massachusetts, United States, February 29.

Puaschunder, Julia Margarete. 2020b. On freedom in the artificial age. Retrieved at https://papers.ssrn.com/sol3/papers.cfm?abstract_id $=3544348$.

Puaschunder, Julia Margarete. 2020c. "Revising growth theory in the Artificial Age: Putty and clay labor." Archives in Business Research 8(3): 65-107.

Sintomer, Y. 2016. Das demokratische Experiment: Geschichte des Losverfahrens in der Politik von Athen bis heute. Wiesbaden: Springer.

Stüwe, K. \& Weber, G. 2004. Antike und modern Demokratie. Stuttgart: Reclam.

de Tocqueville, Alexis. 1848. "De la démocratie en Amérique." Retrieved at https://oll.libertyfund.org/titles/tocqueville-de-la-democratie-en-amerique-4-vols-12th-ed-1848. 